\title{
INSEMINAÇÃO ARTIFICIAL OVINA COM SÊMEN REFRIGERADO APLICADO EM DIFERENTES VIAS
}

\author{
DIFFERENT WAYS OF SHEEP ARTIFICAL INSEMINATION \\ USING COOLED SEMEN
}

\author{
Viviane MILCZWSKI \\ Orientador: Professor Dr. Luiz Ernandes KOZICKI \\ Departamento de Medicina Veterinária - UFPR
}

\begin{abstract}
RESUMO
O presente trabalho objetivou inicialmente comparar a eficiência in vitro de 6 diluentes na conservação de sêmen ovino à temperatura de $5^{\circ} \mathrm{C}$ por 8 horas. Em uma segunda etapa 140 ovelhas foram inseminadas para avaliação de 2 dos diluentes que demostraram maior eficiência in vitro, pelas vias cervical superficial e intra-uterina, em diferentes momentos de aplicação após a sincronização do estro. Foram constituídos 23 homogeneizados de sêmen, diluídos em 6 alíquotas, nos quais foram acrescidos os diluentes Cornell University Extender (CUE), Cornell University 16 (CU-16), glicina-gema, citrato-gema, TRIS-gema e leite desnatado UHT-gema. Após 8 horas de refrigeração o sêmen diluído foi submetido a análise de turbilhonamento, motilidade progressiva, vigor, morfologia espermática e ao teste de termo-resistência (TT) por 4 horas. O citrato-gema apresentou resultados superiores em relação aos demais diluentes e glicina-gema foi inferior $(P<0,05)$. No TT o citrato-gema apresentou resultados superiores, concluindo o teste com $50 \%$ de motilidade progressiva média, porém os diluentes glicina-gema e leite-gema demonstraram motilidade progressiva próxima a zero ao final do teste. Não foram observadas diferenças significativas na proporção de defeitos maiores e desprendimento de acrossoma em quaisquer dos 6 diluentes após 8 horas de refrigeração. Observou-se aumento significativo de caudas enroladas em todas as amostras de sêmen, exceto nas com glicina-gema. Analisando todas as caraterísticas estudadas in vitro, verificou-se que o diluente citrato-gema apresentou melhor preservabilidade do sêmen de carneiro, seguido pelo CUE. Esses 2 diluentes foram submetidos à avaliação in vivo, inseminando-se

140 ovelhas mestiças Suffolk, as quais tiveram o estro sincronizado com pessários vaginais impregnados com $50 \mathrm{mg}$ de acetato de medroxiprogesterona, permanecendo por 14 dias, quando se administrou $500 \mathrm{UI}$ de Equine Chorionic Gonadotrophin intramuscularmente. A aplicação do sêmen foi pela via cervical e intra-uterina por laparoscopia. A utilização do diluente CUE resultou em $69,56 \%(n=23)$ e $8,33 \%(n=24)$ de prenhez para as vias intrauterina e cervical, respectivamente contra $85,71 \%$ ( $n=21)$ e $1,74 \%$ $(n=23)$ para o diluente citrato. O sêmen diluído em citrato-gema forneceu índices de prenhez superiores, porém não significativos $(P>0,05)$, nas duas vias estudadas em relação ao CUE. Esses resultados de prenhez confirmam o experimento realizado in vitro, quando se verificou superioridade do diluente citrato-gema. A taxa de prenhez de ovelhas inseminadas com diluente citrato-gema no mesmo horário após a retirada dos pessários, forneceu $85,71 \%$ e $43,75 \%$ de prenhez nas vias intra-uterina e cervical, respectivamente. A fertilidade foi superior quando se utilizou a via intra-uterina $(P<0,05)$ nos 2 diluentes testados. As inseminações realizadas por via cervical com sêmen refrigerado em citrato-gema às 57 horas e às 49 horas após a retirada dos pessários, obtiveram $43,75 \%$ e $21,74 \%$ de prenhez, respectivamente. O grupo inseminado às 57 horas, apresentou resultados superiores $(P<0,05)$. Foi possível refrigerar o sêmen ovino por 8 horas em citrato-gema obtendo-se boas taxas de prenhez quando se utilizou a via intra-uterina, porém os resultados foram razoáveis na inseminação cervical superficial. A capacidade de fertilização do sêmen refrigerado é satisfatória desde que seja depositado próximo ao sítio de fertilização.
\end{abstract}

\section{ABSTRACT}

The aim of this work was to compare in vitro efficiency of 6 extenders in the conservation of ram semen at $5^{\circ} \mathrm{C}$ for 8 hours. Subsequently, with best in vitro results were used to inseminate 140 ewes. Twenty-three pooled ejaculates were diluted in 6 extenders: Cornell University Extender (CUE), Cornell University - 16 (CU-16), glycine-yolk, citrate-yolk, TRIS-yolk and UHT skim milk-yolk. After $1+3$ dilution, the semen samples were cooled during 8 hours at $5^{\circ} \mathrm{C}$ following analysis of progressive motility, vigor, wave motion, morphology of spermatozoa and thermoresistance test (TT). Citrateyolk extended semen results were significantly $(P<0.05)$ superior. Glycine-yolk extended semen results were significantly inferior. During TT, citrate-yolk extended semen demonstrated the best results $(P<0.05)$, finishing the test with tghe average of $50 \%$ of progressive motility. When glycine-yolk an UHT skim milk-yolk extenders were used progressive motility was near zero. There were no significant differences in percentage of major defects and detached acrosomal caps with all 6 diluters after 8 hours of conservation. CUE, CU-16, citrate-yolk, TRIS-yolk and UHT skim milk-yolk extended semen showed significantly increased rates of bent tail. When all characteristic studied in vitro were analyzed, the citrate-yolk extende showed the best semen preservability followed by CUE. So both were evaluated in vivo with cooled semen for 8 hours at $5^{\circ} \mathrm{C}$. One hundred and forty crossbred Suffolk ewes had the estrus synchronized with intravaginal pessaries containing $50 \mathrm{mg}$ of medroxyprogesterone acetate. In the fourteenth day, at the same time of the removal of the pessaries, $500 \mathrm{UI}$ of Equine Chorionic Gonadotrophin (eCG), were injected intramuscularly. Cervical and intrauterine insemination were performed with the aid of a laparoscope. CUE extended semen showed insemination pregnancy rates of $69.56 \%$ and $8.33 \%$ with the uterine and cervical methods respectively. Citrate-yolk extended semen showed $85.71 \%$ and $21,74 \%$ with the uterine and cervical methods respectively. Citrate-yolk extended semen resulted in higher pregnancy rates, using both insemination methods, however, without statistic significance $(P>0.05)$. These insemination rates confirmed in vitro performances in which citrate-yolk extended semen demonstrated superiority results. The pregnancy rates of the groups inseminated with cooled semen extended in citrate-yolk, 55-58 hours after pessaries removal were $85.75 \%$ and $43.75 \%$ for intrauterine and cervical insemination, respectively. There was significant difference $(P<0.05)$ between the groups. The cervical inseminations with cooled semen extended in citrate yolk at $57 \pm 1$ hours and $49 \pm 1$ hours after pessaries removal, resulted in $43.75 \%$ and $21.74 \%$ pregnancy rates, respectively. The group inseminated at $57 \pm 1$ hours presented significantly superior results $(\mathrm{P}<0.05)$. It was possible cool ram semen for 8 hours in citrate-yolk extender with good pregnant rates when intrauterine insemination was used, but the results were modest when cervical inseminations were used. The fertilization capability of cooled ram semen is satisfactory in the semen is deposited near the fertilization site. 